\title{
Isolation of Rat Lung Mast Cells for Purposes of One-Week Cultivation Using Novel Percoll Variant Percoll PLUS
}

\author{
J. KUBRYCHT ${ }^{1}$, H. MAXOVÁ ${ }^{1,3}$, O. NYČ ${ }^{6}$, L. VAJNER $^{1,4}$, J. NOVOTNÁ $^{1,5}$, \\ A. HEZINOVÁ ${ }^{1,3}$, A. TRNKOVÁ ${ }^{1}$ K. VRABLOVÁ ${ }^{1,4}$, R. VYTÁŠEK ${ }^{1,5}$, V. VALOUŠKOVÁ ${ }^{1,2}$ \\ ${ }^{1}$ Center for Cardiovascular Research, Prague, Czech Republic, ${ }^{2}$ Department of Physiology, Second \\ Faculty of Medicine, Charles University, Prague, Czech Republic, ${ }^{3}$ Department of Pathological \\ Physiology, Second Faculty of Medicine, Charles University, Prague, Czech Republic, ${ }^{4}$ Department \\ of Histology and Embryology, Second Faculty of Medicine, Charles University, Prague, Czech \\ Republic, ${ }^{5}$ Department of Medical Chemistry and Biochemistry, Second Faculty of Medicine, \\ Charles University, Prague, Czech Republic, ${ }^{6}$ Department of Microbiology, Second Faculty of \\ Medicine, Charles University, Prague, Czech Republic
}

Received January 4, 2010

Accepted April 16, 2010

On-line June 9, 2010

\section{Summary}

Prolonged cultivation of separated rat lung mast cells (LMC) in vitro is necessary to better investigate a possible role of LMC in different stages of tissue remodeling induced by hypoxia. Rat lung mast cells (LMC) were separated using a protocol including an improved proteolytic extraction and two subsequent density gradient separations on Ficoll-Paque PLUS and a new generation of Percoll, i.e. Percoll PLUS. Instead of usual isotonic stock Percoll solution, an alternative "asymptotically isotonic" stock solution was more successful in our density separation of LMC on Percoll PLUS. Separated cells were cultivated for six days in media including stem cell factor, interleukins IL-3 and IL-6, and one of two alternative mixtures of antibiotics. These cultivations were performed without any contamination and with only rare changes in cell size and morphology. Model co-cultivation of two allogenic fractions of LMC often caused considerable rapid changes in cell morphology and size. In contrast to these observations no or rare morphological changes were found after cultivation under hypoxic conditions. In conclusions, we modified separation on Percoll PLUS to be widely used, altered LMC separation with respect to purposes of long-lasting cultivation and observed some model morphological changes of LMC.

\section{Key words}

Hypoxia - Lung mast cells - Percoll - C-kit - Progenitor • Secretion

\section{Corresponding author}

J. Kubrycht, Department of Physiology, Second Medical School, Charles University, Plzeňská 221, 15000 Prague 5, Czech Republic. Fax: +420 257210995. E-mail: jkub@post.cz

\section{Introduction}

Hypoxia-induced pulmonary hypertension accompanies several serious lung diseases, and is also involved in some cardiovascular complications (Herget and Ježek 1989). Lung mast cells (LMC) participate in the mechanisms of vascular tissue remodeling activated by hypoxia (Vajner et al. 2006, Maxová et al. 2008). Immediate and early responses of LMC to hypoxia are triggered with competent receptors, adhesive molecules and oxygen/superoxide sensors (Manalo et al. 2005, Bell et al. 2007, Theoharides et al. 2007, Brown and Nurse 2008).

Mast cells (MC) can be prepared from pluripotent progenitors (PMC) using long-term cultivation lasting at least seven weeks (Holm et al. 2008). Such cultivations generate viable and well proliferating PMC. PMC are usually better adapted to the in vitro conditions than LMC. On the other hand, such type of preparation increases the risk of in vitro artifacts. This is a reason, why LMC are still proteolytically extracted from tissues in some experiments (Holt et al. 
1985, de Paulis et al. 2001, Cruse et al. 2005, Kim et al. 2005, Maxová et al. 2008) in spite of difficulties accompanying tissue extraction and low-yield separation (Holm et al. 2008). Interleukins 3 and 6 (IL-3, IL-6) and stem cell factor (SCF) has been considered as cytokines necessary for mast cell cultivations in the last 10 years (Andersen et al. 2008).

In this paper, we modified previously used separation of rat LMC (Maxová et al. 2008) for the purpose of at least six-day cultivation. In addition, we utilized a new, yet very rarely employed more stable version of the cell separation medium Percoll, i.e. Percoll PLUS substituting usual Percoll dilution by "asymptotically isotonic" dilution. Percoll PLUS was used individually or together with Ficoll Paque PLUS, which diminishes side adherences worsening cell purity. In accordance with the data of Wu et al. (2008) we found predominantly immature LMC among the separated cells exhibiting c-kit positivity. This immature stage is possibly a reason why frequent c-kit positive cells of fibroblast-like phenotype can be observed in response to model allogenic stimulation after cultivations lasting more than three days. Our experiments represent the starting point to experimental in vitro cultivations. Such cultivations lasting from half hour to three days would be preceded by three-day relaxation period diminishing the consequences of necessary brutal tissue extraction of LMC.

\section{Methods}

\section{Animals, chemicals and equipment}

Adult male Wistar specific pathogen-free rats (Anlab, Prague, Czech Republic) weighing 300-450 g were used in each of our twelve LMC separations (3-9 rats per experiment). Lung extractions were performed in accordance with the European Community and NIH guidelines for using experimental animals and were approved by Animal Studies Committee of our institution. RBL-2H3 cell line was obtained from ATCCLGC (Teddington, United Kingdom). Fetal calf serum was purchased from Biochrom (Berlin, Germany). Media RPMI1640 and E-MEM both with 20m M HEPES, an antibiotic mixture "antibiotic antimycotic solution", antibiotic amphotericin B, Red blood cell lysing buffer, Corning filters $0.2 \mu \mathrm{m}$ and chemiluminiscent peroxidase substrate 3 were all delivered by Sigma-Aldrich (St. Louis, Missouri). The antibiotics ampicillin (Biotika,
Slovenská L’upča, Slovakia) and gentamycin (Lek Pharmaceuticals, Ljublana, Slovenia) were also used in our cultivations. New almost inert Percoll variant Percoll PLUS and another cell separation medium Ficoll Paque PLUS (FPP) were obtained from GE Health Care (Uppsala, Sweden). All essential cytokines, i.e. IL-3, IL-6 and SCF were purchased from Peprotech (Rocky Hill, New Jersey) or Prospec (Ness-Ziona, Israel). Plates and Labteks (Thermo Fisher Scientific, Kamstrupvej, Denmark) were in some experiments placed into incubator chamber of two-liter volume (BillupsRothenberg Inc., Del Mar, California), which keeps hypoxic environment. Contaminating bacteria and spongi were identified by biochemical tests delivered by API Bio Mérieux (Marcy l'Etoile, France). Peroxidase chemiluminiscent staining was developed in Kodak Image Station (Kodak, New York, New York).

\section{Media for LMC separation and cultivation}

Media R0.5 R2, R5 contained 99.2\%, $97.7 \%$, $94.7 \%$ of RPMI 1640 (with 20 mM HEPES) and $0.5 \%$, $2 \%$ or $5 \%$ of fetal calf serum (FCS), respectively, together with gentamycin (final non-toxic concentration $120 \mu \mathrm{g} / \mathrm{ml}$ ). Medium R5_2E and R0.5_2E contained $99 \%$ R5 or R0.5, respectively, and $1 \% 200 \mathrm{mM}$ EDTA $\mathrm{pH}$ 7.5. In accordance with DSMZ protocol for cultivation of cell line RBL-2H3 (i.e. a line used as a mast cell model; cf. www.dsmz.de), primary tissue culture medium (PTC medium) contained $70 \%$ MEM (with Earle's salts), $20 \%$ RPMI 1640, $10 \%$ FCS and gentamycin (final concentration $120 \mu \mathrm{g} / \mathrm{ml}$ ). Similar proteinase incubation medium (PI medium) then included $10 \%$ of additional RPMI instead of FCS. To prepare our cultivation medium we added amphotericin B (fungison) and ampicillin to PTC medium in order to achieve their final concentrations $7.5 \mu \mathrm{g} / \mathrm{ml}$ and $3 \mu \mathrm{g} / \mathrm{ml}$, respectively. In addition, all the cytokines SCF, IL-3 and IL-6 were present in the same medium at final concentrations $20 \mathrm{ng} / \mathrm{ml}$ (Arinobu et al. 2005).

\section{Separation and cultivation of mast cells}

\section{Schemes of separation}

The schemes of our initial and final protocols are shown in Table 1. For unchanged procedures see the previous paper (Maxová et al. 2008).

\section{Soaking procedure and proteolytical extraction (PE)}

Soaking procedure comprised repeating steps including cutting of still floating lung fragments (LF) and 
Table 1. Schemes of LMC separation.

Original protocol a (Maxová et al. 2008)

lung perfusion
segmentation to lung fragments (LF)
collection of $L F$ from four rats
processing $L F$ with trypsin
proteolytical extraction
clumps of non-digested tissue were removed using a sieve
preformed continuous Percoll gradient
washing ( $300 \mathrm{~g}, 30$ min in RPMI 1640)

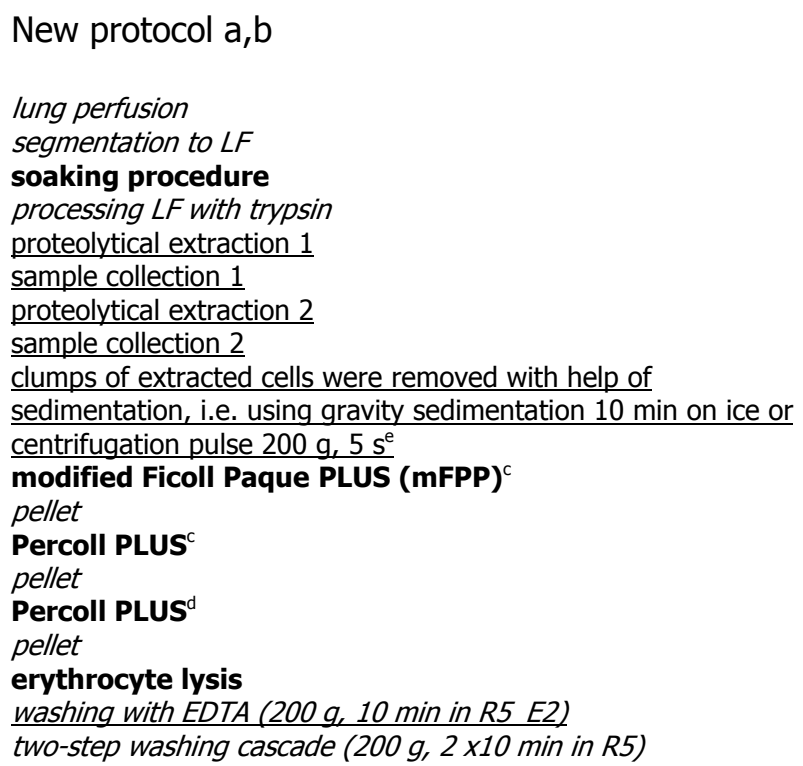

New protocol a,b

lung perfusion

segmentation to $L F$

soaking procedure

processing LF with trypsin

proteolytical extraction 1

sample collection 1

proteolytical extraction 2

sample collection 2

clumps of extracted cells were removed with help of

sedimentation, i.e. using gravity sedimentation $10 \mathrm{~min}$ on ice or

centrifugation pulse $200 \mathrm{~g}, 5 \mathrm{~s}^{\mathrm{e}}$

modified Ficoll Paque PLUS (mFPP)

pellet

Percoll PLUS

pellet

Percoll PLUS

pellet

erythrocyte lysis

washing with EDTA (200 q, 10 min in R5 E2)

two-step washing cascade (200 $\mathrm{g}, 2 \times 10 \mathrm{~min}$ in R5)

\begin{abstract}
${ }^{a}$ Original protocol represents LMC separation for purposes of short experimental cultivations lasting usually one day. Italics - unchanged procedures; italics underlined - different procedures mentioned only here; underlined - modifications are mentioned in the text; bold new or markedly different procedures described or explained in the text. ${ }^{b}$ For additional details see Methods. ${ }^{c, d}$ An alternative procedure including either subsequently employed mFPP and Percoll PLUS or solely Percoll PLUS, respectively. ${ }^{\mathrm{e}}$ For similar pulse see Soaking procedure and proteolytical extraction.
\end{abstract}

collection of LF pelleted by centrifugation pulses (each centrifugation pulse comprised: i) fast acceleration to $400 \mathrm{~g}$, ii) keeping maximum speed for one second, iii) braked deceleration to $150 \mathrm{~g}$, and iv) final deceleration without braking). Soaked LF were two times incubated for $40 \mathrm{~min}$ in $2-3 \mathrm{ml}$ aliquots of proteinase mixture completed by delayed addition of 0.4-0.6 ml DNAase after $20 \mathrm{~min}$ of each PE (proteinase mixture: $5 \mathrm{mg}$ collagenase, $5 \mathrm{mg}$ hyaluronidase and $0.25 \mathrm{ml}$ elastase in $16 \mathrm{ml}$ of PI; DNAase solution: $1 \mathrm{mg}$ DNAse were solved in $4 \mathrm{ml}$ of PI; both solutions were filtered). Both PE included two one-minute circular shakings occurring after each 20-min lasting period. The transfer of released cells to R5 terminated both PE (centrifugation $15 \mathrm{~min}, 300 \mathrm{~g}$ ).

Separation of LMC on discontinuous gradients of Percoll PLUS and modified FPP

Instead of usual isotonic Percoll (Maxová et al. 2008), we prepared asymptotically isotonic Percoll PLUS (AIPP contained $22.73 \mathrm{ml}$ of Percoll PLUS and $2.27 \mathrm{ml}$ $1.5 \mathrm{M} \mathrm{NaCl}$, see also the first section of Results) by mixing with Percoll PLUS with R0.5_2E to perform $12 \mathrm{ml} 35 \%, 75 \%$ and $90 \%$. Cell suspensions in R5 were applied to six probes with preformed gradients and centrifuged for $20 \mathrm{~min}(400 \mathrm{~g}$, in accordance with GE Health Care handbook 18-1115-69). Separation of LMC was performed individually or after separation on modified FPP. In latter case, $0.1 \%$ volume of FCS was added to FPP immediately before separation and resulting solution was filtered (filter cut off limit $0.2 \mu \mathrm{m}$ ). This filtered solution was then used in separation of LMC fraction accumulating in a pellet $(250 \mathrm{~g}, 15 \mathrm{~min}$, $\left.18-25{ }^{\circ} \mathrm{C}\right)$.

\section{Erythrocyte lysis}

Supernatants were thoroughly splashed away after Percoll centrifugation. Pelleted cells were resuspended in $0.7 \mathrm{ml}$ of erythrocyte lysing buffer, incubated one minute in flow box and diluted by $2.8 \mathrm{ml}$ of cold R5_2E.

Prevention of cell clumping and diminishing of interactions between bacteria and separated cells

To prevent accumulative formation of cell clumps we used: i) FCS in all media (FCS was also present in concentration $0.5 \%$ in medium R0.5_2E diluting Percoll PLUS), ii) cooled centrifuges and probes in ice, iii) cell suspension without initial clumps (discarded after proteolytical extraction). The interactions of separated cells with bacteria were blocked by: i) cleavage of interacting molecules during proteolytical extraction or ii) inhibition of such interactions in presence 
of $2 \mathrm{mM}$ EDTA during subsequent cell separation. The effect of EDTA concerns first of all widely spread interactions between i) lectins or integrins and ii) bacterial cell surface molecules (Smith 1997, Hosoi et al. 1998, Zelensky and Gready 2005, Eto et al. 2007, Yu et al. 2007).

Cultivation, hypoxic cultivation and transfer of LMC fraction

Majority of in vitro cultivations occurred in sterile LabTek using our cultivation medium. Three-daylasting pre-cultivations preceding hypoxia exposure were carried out to minimize the most frequent cell-death events initiated during the starting cell separation (Bischoff et al. 1999). During hypoxic experiments in vitro, cells were placed into modulator incubator chamber with $3 \% \mathrm{O}_{2}, 5 \% \mathrm{CO}_{2}$ and $92 \% \mathrm{~N}_{2}$. Gas equilibration was performed for $15 \mathrm{~min}$ by gas flow rate of $21 / \mathrm{min}$. All cells of LMC tissue culture were detached from well surface after 10-min incubation with $0.2 \%$ trypsin in PBS (similarly to cell line RBL-2H3, cf. www.lgcstandards-atcc.org).

\section{Experimental procedures and their evaluation}

Microbiological analysis

Samples (media, washings or cell suspensions) were transferred to nine volumes of amplifying thioglycolate buoyant Dulab and incubated 18-24 h at temperature $35{ }^{\circ} \mathrm{C}$ in aerobic environment. The resulting solutions were transferred to the blood, End's and Saboraud's agars and incubated $36 \mathrm{~h}$ in the same temperature. Macroscopical and microscopical morphologies and standard biochemical tests were used to identify contingent colonies of microbes.

\section{Cytological analysis}

Toluidine blue, peroxidase-DAB visualization with c-kit (CD117) and hematoxylin counterstaining enabled us to check cell phenotype and maturation stage of methanol-fixed LMC (Churukian and Schenk 1982, Avivi et al. 1994). At least 10 different cell numbers obtained in five defined sites (microsamples) of at least two Labtek wells formed minimal data set.

\section{Detection of MMP13 in exosomes of $R B L-2 H 3$}

Exosomes present in two times filtered (filter cut off limit $0.2 \mu \mathrm{m}$ ) medium (presedimented by two subsequent centrifugations $500 \mathrm{~g}, 10 \mathrm{~min}$ ) from six-day tissue culture of $10^{7}$ RBL-2H3 cells were sedimented by ultracentrifugation (100 000 g, 2 h). Vortexed exosomes were solved in sample buffer for SDS electrophoresis and heated up for $5 \mathrm{~min}$ in boiling bath. Resulting solution was then diluted to achieve exosome amounts corresponding to rounded off numbers of source RBL$2 \mathrm{H} 3$ cells. For electrophoretic and blotting procedures see Maxová et al. (2008). The peroxidase immunostaining of blot replica was performed with our monoclonal antibody against MMP13, peroxidase substrate 3, the corresponding Sigma protocol and light sensitive camera present in Kodak Image Station.

\section{Statistical evaluation}

All calculations were performed on minicomputer Casio Algebra PLUS. The evaluation included programming in Basic language comprising functions which enabled us the use of implemented statistic modules of the given minicomputer (for formulas see Komenda 1997 and Zvárová 2001). Each statistical limit $(\mathrm{n}+)$ was determined with help of one-side Student's t-test according to the formula:

$\mathrm{n}+=\mathrm{n}^{*}+\mathrm{Q}(\mathrm{w}, \mathrm{df}) \times \mathrm{S}$

where $n^{*}$ is mean value, $Q(w, d f)$ was the corresponding quantile, $w$ denoted significance level and $S$ is overall group-related standard deviation. Usually holds that $\mathrm{df}=\mathrm{k}+\mathrm{m}-2$ (where $k$ and $m$ are numbers of compared values in two sets) but here we related $S$ to the mean value defined by single set (ten numbers) only (cf. section Cytological analysis). Consequently, we used more skeptical (i.e. higher limit related) statistical estimation determined by the single set derived $\mathrm{df}=\mathrm{k}-1$. S was defined by the formula:

$\mathrm{S}^{2}=\left\{(1 / \mathrm{k}+1 / \mathrm{m})^{0.5}\right\} \times\left\{(\mathrm{k}-1) \times \mathrm{S}_{1}{ }^{2}+(\mathrm{m}-1) \mathrm{S}_{2}{ }^{2}\right\} /(\mathrm{k}+$ $\mathrm{m}-2)$,

where $S_{1}$ and $S_{2}$ are standard deviations of the first and second sets, respectively (Zvárová 2001).

\section{Results}

Innovations and improvements in cell separation by Percoll

Currently prepared initial (apparently) "isotonic" $100 \%$ Percoll was less efficient in cell separation than that of Percoll PLUS. This conclusion was implicated by marked difference between expected and observed layer 
distributions of separated cells. Since weak hypotonicity is recommended for related separation of leukocytes (280-300 mOsmol/1) by Boyum et al. (2002), we prepared an "asymptotically isotonic" $100 \%$ Percoll PLUS solution (AIPP; related to maximum achievable osmolality of commercially accessible stock Percoll PLUS $30 \mathrm{mOsmol} / \mathrm{kg}$ ) instead of current initial "isotonic" $100 \%$ solution. It means that we shifted the maximum possible concentration of Percoll PLUS following from the current Percoll dilution, i.e. about $327 \mathrm{mOsmol} / 1$, to the upper AIPP-related optimum value $300 \mathrm{mOsmol} / \mathrm{l}$. In fact, this represented a simple mixing of ten volumes of Percoll PLUS and one volume of $1.5 \mathrm{M} \mathrm{NaCl}$, instead of the corresponding nine volumes of Percoll in the original procedure.

Separation on AIPP-derived gradients achieved sufficient agreement with expected layer distribution of cells indicating layers with: i) dead cells (35\% AIPP), ii) leukocytes and fibroblasts (75\% AIPP), iii) thin or no residual cell impurities (90\% AIPP) and iv) mast cells and residual erythrocytes (pellet).

The quality AIPP-related gradient was also tested by means of density marker beads (DMB). In accordance with desired mast cell density range (1.102$1.119 \mathrm{~g} / \mathrm{ml}$, Maxová et al. 2008), green DMB (density $1.098 \mathrm{~g} / \mathrm{ml}$ ) were located about $2 \mathrm{~cm}$ under bottom floating on the layer $90 \%$ AIPP, whereas the red DMB (density $1.120 \mathrm{~g} / \mathrm{ml}$ ) were present in pellets. We did not observe any substantial differences between yields of separations, when comparing Percoll and Percoll PLUS. However, gradual failing of separations on Percoll appeared after about three months of its usage, whereas Percoll PLUS still worked after one year.

\section{Combination of modified FPP and Percoll PLUS}

Two-step separation resulted in the yield of about 20-60 \% cells compared to one-step Percoll fractionation (i.e. 5-25 × 10 4 cells per single rat lung), but substantially diminished well-observable cell adherences to sides of employed probes. These adherences were located in density boundary lines between density Percoll layers resembling to beer rings on glass. Partial diminishing of side adherences was also achieved by application of cells to Percoll PLUS gradients in R5 medium. Resulting cell suspension of LMC, uninfluenced by any corpuscular interaction, achieved 70-90\% purity determined by c-kit expression after three- or six-day cultivations.

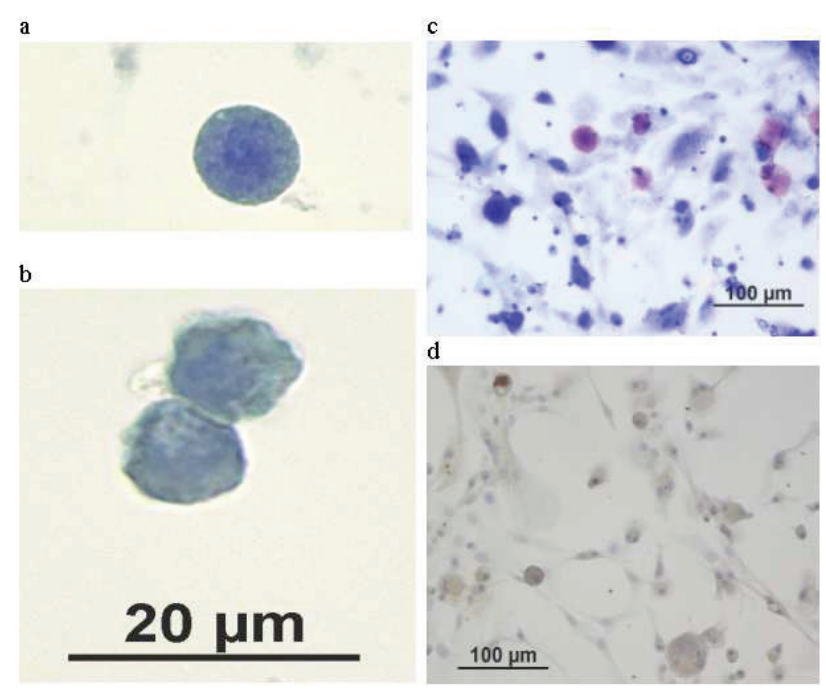

Fig. 1. Morphology of cultivated lung mast cells. a, b, c- six-day cultivation, $\mathrm{d}$ - three-day cultivation; $\mathrm{a}, \mathrm{b}$ - comparable toluidine blue staining after hypoxic or normoxic cultivations, respectively; c, d - cells after one-step separation using Percoll PLUS only; c purple metachromatic mature and blue immature LMC; d staining with $\mathrm{DAB}$ and hematoxylin indicating simultaneous presence of fibroblasts ("gray cells") and c-kit positive fibroblastlike cells and giant LMC ("brown cells").
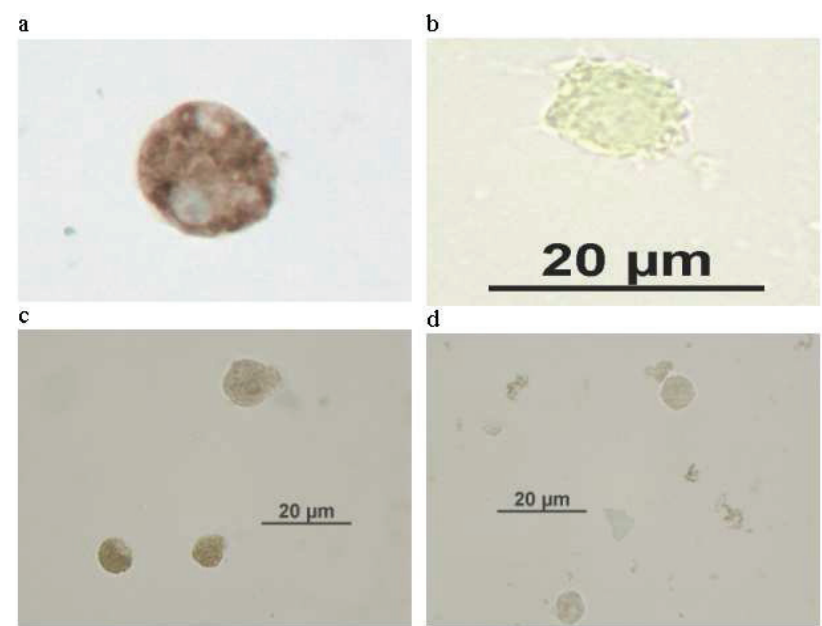

d

Fig. 2. Immunohistochemical detection of c-kit with LMC. a,c c-kit-positive cells; b,d - negative controls; $a, b$ - six-day cultivation; c, d - three-day cultivation.

\section{Microbiological screening}

The new antibiotic mixture (ATB3) described in Methods enabled us even sixty-day cultivation without any contamination. The occurrence of contamination in case of current experiments was lower than $5 \%$ and included Acinetobacter spp., Staphyloccocus epidermidis (necessity of gloves usage during mast cell preparation). Nevertheless, frequent contamination can sometimes occur when adding pig pancreatic elastase I (lung cell extracting enzyme) without mixing to the PI medium (crystal of enzymes remain in bottom of stock solution). 


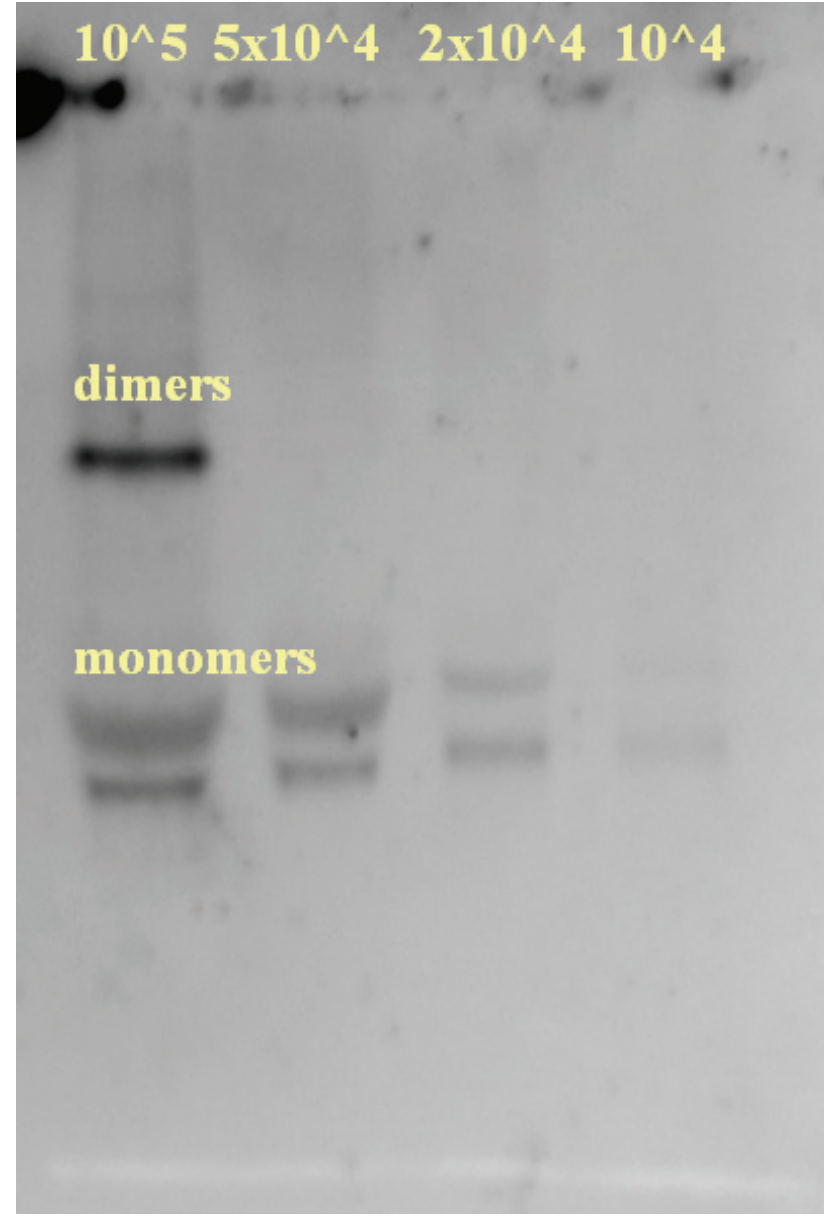

Fig. 3. Blotting detection of MMP13 in exosomes from model cell line RBL-2H3. MMP13 was still detected in minimum amount corresponding to $10^{4}$ of source RBL-2H3 cells. We can also observe single band with MMP13 dimers (caused by low dilution of preparation with sample buffer), and double-bands containing larger pro-enzyme and smaller active form of MMP13 (Novotná and Herget 2002). For details of blotting detection see Methods.

\section{Morphology of separated rat LMC cultivated after separation}

In accordance with findings of Wu et al. (2008) a majority of LMC separated by our procedures exhibited immature morphology (Figs 1 and 2). Some preparations of LMC included among others also the cells, which seemed to contain two or several nuclei. This apparent nuclear duplicities or multiplicities were possibly caused by nuclear segmentation (cf. Discussion).

Surprisingly, some fibroblast-like cells were c-kit positive (Fig. 2) indicating thus morphological but not phenotypic deviations. However, these cells and fibroblast impurities grew more rapidly than spherical cells. Fibroblast-like cells were also observed after some one-step Percoll separations (Figs $2 \mathrm{~b}$ and 2d) and during model allogenic reaction (Table 2). Proliferation of spherical cells in LMC tissue culture usually ceased
Table 2. Model cultivation of separated cells.

\section{Experimental values and Cell proliferation and calculated limits ${ }^{\mathrm{a}}$ morphology}

\begin{tabular}{|c|c|c|c|c|c|c|}
\hline & n3* & n6* & S.D. & n3+ & $\operatorname{div} / \mathrm{day}^{\mathrm{b}}$ & phenotype $^{c}$ \\
\hline${ }^{d} 1$ & 3.20 & 5.80 & 0.88 & 4.81 & 0.286 & $\mathrm{f}-, \mathrm{n}(\mathrm{l})$ \\
\hline 2 & 2.90 & 6.50 & 0.83 & 4.41 & 0.388 & $\mathrm{f}-\mathrm{f}(\mathrm{l}), \mathrm{n} / \mathrm{l}$ \\
\hline 3 & 4.10 & 10.40 & 1.43 & 6.72 & 0.448 & $\mathrm{f}+, \mathrm{n} / 1 \_1$ \\
\hline 4 & 7.10 & 19.90 & 2.41 & 11.52 & 0.496 & $\mathrm{f}++, \mathrm{vl}$ \\
\hline 5 & 3.70 & 5.90 & 0.66 & 4.91 & 0.224 & $\mathrm{f}-, \mathrm{n} \_\mathrm{n}(\mathrm{l})$ \\
\hline 6 & 3.40 & 5.70 & 0.90 & 5.05 & 0.248 & $\mathrm{f}(1), \mathrm{n}(1)$ \\
\hline 7 & 4.90 & 8.90 & 0.88 & 6.52 & 0.287 & $\mathrm{f}(\mathrm{l}), \mathrm{n}(\mathrm{l}) \_\mathrm{n} / \mathrm{l}$ \\
\hline 8 & 6.30 & 14.00 & 1.27 & 8.62 & 0.384 & $\mathrm{f}++, \mathrm{vl}$ \\
\hline
\end{tabular}

aSignificant proliferation and different morphologies were observed in our differently cultivated samples. This conclusion follows from the comparison of $\mathbf{n} \mathbf{3}+$ and $\mathbf{n} 6 *$ values. $\mathbf{n} \mathbf{3}+-$ $n 6^{*}$ values higher than $\mathrm{n} 3+$ are significantly higher $(\mathrm{w}=0.05)$ than n3*; n3*, n6* - mean numbers of cells after three and six days of cultivation, respectively; S.D. - group-related standard deviations. For additional comments see last section of Results. ${ }^{b}$ div/day - Proliferation rate (PR) denoting number of cell divisions per day $\left(P R=\log \left(n 6^{*} / \mathrm{n}^{*}\right) /(\right.$ days $\mathrm{x} \log 2)$, where days $=6-3=3)$. ' ${ }^{c}$ cell size and morphology after 6 days of cultivation: $\mathrm{f}--$ absence of cells with fibroblast phenotype (CFP); $f(I)$ - low occurrence (less than $10 \%$ ) of CFP; $\mathrm{f}+-$ comparable numbers of normal cells and CFP; $\mathrm{f}++-$ predominant occurrence of CFP; $n$ - normal size (original size of freshly isolated LMC); $\mathrm{n}(\mathrm{l})$ - normal cell size and low occurrence (less than $10 \%$ ) of larger cells; $\mathrm{n} / \mathrm{l}$ - comparable numbers of normal size and large cells; I - dominant occurrence of large cells; $\mathrm{vl}$ - majority of cells was substantially higher than the cells classified as large. ${ }^{d}$ rows including data: 1-4 - cultivation with SCF, IL-3, IL-6; rows 5-8 in addition to the preceding cytokines we added filtered (cut off limit $0.2 \mu \mathrm{m}$ ) medium from 6 day RBL-2H3 cultivation to its final $10 \%$ dilution in the original cultivation medium; odd, even rows - our mixture of 3 antibiotics or "antibiotic antimycotic solution" were added to media, respectively; rows 1,2,5,6 - autologous cells; rows $3,4,7,8$ allogenic cells.

after 10-15 days of cultivations, whereas the fibroblast and fibroblast-like cells still proliferated.

5-30\% lower fractions of fibroblast-like cells were found when comparing model three-day hypoxic cultivations with the normoxic ones. The morphological differences between hypoxic and normoxic cells were not observed when using toluidine blue staining indicating large LMC granules (Fig. 2).

In agreement with this fact, molecules MMP13, found in enlarged amount in LMC after hypoxia (Maxová et al. 2008), were detected by blotting in distinct membrane compartment of model cell line RBL-2H3, i.e. in exosomes representing descendants of small intracellular membrane vesicles invisible with light microscopy (Fig. 3 and Discussion). 


\section{Model cultivation with LMC fraction}

The results presented in Table 2 demonstrate low but significant proliferation rates of LMC during three-day period (meanwhile assumed for experiments), which was preceded by three-day relaxation period (mean cell numbers $6^{*}$ with calculated limit $\mathrm{n} 3+$ in Table 2). The required optimal size and shape was mostly found in the cases of proliferation rate lower than 0.35 divisions per day. Cells cultivated with our antibiotic mixture (odd rows) exhibited: i) less deviated morphology (row pairs $[1,2]$, $[3,4],[5,6],[7,8]$ in Table 2) than those incubated with "antibiotic antimycotic solution" and ii) significantly lower cell growth $(\mathrm{p}<0.05$, paired t-test was used here and in the following part of this section, Komenda 1997). The model samples including allogenic cells from two different Wistar rats (samples 3, 4, 7, and 8) achieved significantly higher proliferation rate $(\mathrm{p}<0.05)$ and more deviated morphology (possibly due to allogenic reaction of residual lymphocytes) than in the culture with autologous cells of single rat origin (compared pairs [1,3], [2,4], [5,7], [6,8]). Samples corresponding to the pairs of table rows: $[1,5]$, $[2,6],[3,7],[4,8]$ differed only by addition of $10 \%$ of filtered cultivation medium without cytokines (or related medium with "antibiotic antimycotic solution") from oneweek cultivation of about $10^{6} \mathrm{RBL}-2 \mathrm{H} 3$ cells (in $10 \mathrm{ml}$ of medium) to the cultivation medium with samples 5-8. This addition of medium derived from RBL-2H3 cells significantly diminished proliferation rates in all compared pairs of samples $(\mathrm{p}<0.02)$ and was accompanied by the almost optimal morphology (Table 2). This effect concerned even the interesting case of model allogenic culture containing our antibiotic mixture ABT3 (rows 3 and 7 in Table 2).

\section{Discussion}

Comparison of our LMC separation with related methods Since the separation of rat LMC is poorly described in the literature, we compare here our method with the methods proposed for separation of human LMC. In comparison with LMC separation using direct interaction with magnetic beads (Cruse et al. 2005) our LMC did not contain interacting residual particles. On the other hand, the compared direct magnetic separation is excellent with respect to purity (98\% of purity) and without any problems when isolating LMC specific lysates for biochemical and molecular biology purposes. In contrast to our method, elutriation appears to be more interesting with respect to short-term cultivations
(Willheim et al. 1995). Hence, the disinfection of elutriation rotor is still carried out simply by a less reliable ethanol (Binda et al. 2009). Nevertheless, the possibility to remove impurities of variously differentiated cells by magnetic separation (Willheim et al. 1995) appears to be an interesting supplement to our future method improvement. However, the immediate improvement is complicated by a small repertoire of necessary anti-rat antibodies.

\section{Problems with contamination}

Separation of LMC for purposes of one-week or longer cultivations is less frequently described in the literature than the other LMC separations (Cruse et al. 2005). The main obstacles result from the air exchange in lung implicating a contamination risk. Among the many effects influencing sterility of cultivation, we consider here: i) effect of proteolysis and low concentrations of EDTA on cell surface interactions (cf. Methods), ii) effect of antibiotics and iii) antifungal and bactericidal effects of proteolysis.

Our introductory microbiological and microscopical screening concerned samples of mast cells separated by Percoll gradient centrifugation, which were cultivated in medium containing gentamycin (G-samples). Analysis of positive G-samples revealed molds and bacterial contaminations sensitive to rifampicin and vancomycin. However, both these antibiotics triggered histamine release in some cases (Nessi et al. 1976, Chiang et al. 1992, Nabe et al. 1999, Toyoguchi et al. 2000) and thus they do not fit to our experiments with mast cells. Subsequently, we decided to introduce ampicillin to the improved medium due to its less specific but important synergistical effect with the previously mentioned gentamycin (Gnarpe et al. 1976) and amphotericin B (fungison) as anti-mold agents.

Pig pancreatic elastase 1 (PPE1) is used together with other enzymes in the extraction of LMC. Substantial part of PPE1 is present in the bottom of its stock bottle in a form of crystals. Consequently, mixing of liquid in this stock bottle enables complete aliquot transfer of this enzyme to extraction mixture, where crystals are dissolved. Since we observed the effect of such bottle mixing on sterility of LMC tissue culture in some our experiments (cf. Results), we proposed bactericide effect of PPE1. However, we did not find any evidence of such bactericide effect of PPE1 in the literature. Only bactericide effect of other elastase, i.e. human neutrophil elastase, was confirmed (HNE; Miyasaki et al. 1991, Newman et al. 
2000). In accordance with our BLASTP search for HNE sequence similarities, PPE1 contained the second most similar segment among vertebrate pancreatic elastases, whereas the segment of pancreatic elastase sequence of Xenopus laevis origin, but not human one, was the most similar (the search was performed in time before the paper submission). This fact suggested marked convergent, if not even functionally driven phylogenetic changes in PPE1 sequence. It appeared to be important in spite of marked sequence difference between PPE1 and HNE-related neutrophil elastase family following from our PSI BLAST/Clustal W-derived phylogram (data not shown). Consequently, the found superior sequence similarities between PPE1 and HNE supported our opinion that PPE1 stock solution mixing represent a one of the important steps necessary for sterility of LMC tissue culture.

\section{Proliferation and morphology of LMC}

In accordance with literature the majority of our LMC represent immature cells (Wu et al. 2008) enabling usually broader variation in phenotype. Rapid proliferation (proliferation rates higher than 0.35 divisions per day) was frequently accompanied by considerable changes in size (enlargement of spherical cells) and rapid changes in morphology including generation of observed fibroblastlike cells (Table 2). Such changes were predominantly observed in model mixtures of allogenic cells (originating from different Wistar rats) generating cytokines. In accordance with expression studies of model human mixed lymphocyte reaction (Kohka et al. 1999, Itoh et al. 2002) and superior expression of interleukin 18-receptor (IL18R1) in human mast cells (item GD1775/206681_at/ IL18R1 present in expression database of NIH), interleukin 18 appears to be a possible candidate for generation of the discussed fibroblast-like cells.

Fibroblast-like morphology of LMC (Fig. 2) is related to morphology of more rapidly growing rat basophilic leukemia cell line RBL-2H3, representing widely used model of mast cells. Nevertheless, the addition of $10 \%$ medium from six-day cultivation of RBL-2H3 to medium with LMC diminished phenotypic changes (spherical cells of unchanged size; Table 2). It is a question whether nerve growth factor, interleukin- 6 or tumor necrosis factor alpha detected in supernatants of uninfluenced RBL-2H3 cells (Suzuki et al. 1998, Onose et al. 2008) participate in such modulation or if we can alternatively assume the effects of membrane particles of 60-90 $\mathrm{nm}$ diameter called exosomes released by both mast cells and model RBL-2H3 cells (Skokos et al. 2002,
Laulagnier et al. 2005).

LMC looking like double- or multi-nuclear cells were observed in some samples (Fig. 2d). In accordance with literature data these cells contain more likely segmented nuclei than actually multiplied nuclei. Hence, mast cells with segmented nuclei are indeed observed in tissue cultures and they can imitate cells with multiplied nuclei in some of their photos (Gurish et al. 1997, Chott et al. 2003).

The observation that hypoxia does not change the density of large (toluidine blue-positive) histamine granules with a diameter of $800-1000 \mathrm{~nm}$ seems to contradict to changes in MMP13 synthesis described in the previous paper (Maxová et al. 2008, Theoharides et al. 2007). This apparent contradiction can be explained by the presence of MMP13 and perhaps other secreted molecules induced by hypoxia in membrane compartment distinct from large granules (see Results and Fig. 3). Based on presented data this compartment is composed of small vesicles with diameter of about 40-80 nm (Theoharides et al. 2007), representing precursors of the separated exosomes (Skokos et al. 2002). The investigated molecule of MMP13 is otherwise important with respect to lung tissue remodeling induced by hypoxia. Hence it disrupts the quaternary organization of triple helix in the collagenase susceptible site initiating thus collagenolysis (Weingarten and Feder 1986, Novotná and Herget 2002). Increased collagenolysis in peripheral pulmonary arteries is then probably one of the important mechanisms that trigger pulmonary vascular remodeling in chronic hypoxia (Vajner et al. 2006).

\section{Conclusions}

We proposed here a new modification concerning Percoll PLUS solutions, which is based on initial "asymptotically isotonic" $100 \%$ Percoll solutions (see Results). This modification enables us to prepare any well-separating Percoll PLUS gradients without measuring of osmotic pressure, which usually causes problems with Percoll PLUS losses or keeping of sterility of this separation medium. Similarly, whole our LMC separation is suitable for sterile cultivations, which last at least six days. In comparison with the LMC separation based on magnetic beads, our separation is less effective and selective, but on the other hand does not cause the artificial LMC activation by separating antibodies (see Discussion). Morphological analysis of cultivated LMC using light microscope suggests extended changes when mixing allogenic fractions of separated LMC, but less 
visible changes in the case of hypoxia. In accordance with our study of model RBL-2H3 exosomes, we assume that the reason for less visible changes after hypoxia would not insist in absence of any LMC response, but more likely in the amplification of membrane vesicles observable only by electron microscopy.

\section{Conflict of Interest}

There is no conflict of interest.

\section{Acknowledgements}

The study was supported by the Grant Agency of the Czech Republic 305/08/0108 and by the Cardiovascular Research Centre MSMT 1M0510.

\author{
Abbreviations \\ FPP - Ficoll Paque PLUS; IL-3 and IL-6 - interleukins 3 \\ and 6, respectively; LF - lung fragments; LMC - lung \\ mast cells; $\mathrm{MC}$ - mast cells; $\mathrm{SCF}$ - stem cell factor.
}

\section{References}

ANDERSEN HB, HOLM M, HETLAND TE, DAHL C, JUNKER S, SCHIØTZ PO, HOFFMANN HJ: Comparison of short term in vitro cultured human mast cells from different progenitors - peripheral blood-derived progenitors generate highly mature and functional mast cells. J Immunol Methods 336: 166-174, 2008.

ARINOBU Y, IWASAKI H, GURISH MF, MIZUNO S-I, SHIGEMATSU H, OZAWA H, TENEN DG, AUSTEN KF, AKASHI K: Developmental checkpoints of the basophil/mast cell lineages in adult murine hematopoiesis. Proc Natl Acad Sci USA 102: 18105-18110, 2005.

AVIVI C, ROSEN O, GOLDSTEIN RS: New chromogens for alkaline phosphatase histochemistry: salmon and magenta phosphate are useful for single- and double-label immunohistochemistry. J Histochem Cytochem 42: 551-554, 1994.

BELL EL, KLIMOVA TA, EISENBART J, MORAES CT, MURPHY MP, SCOTT BUDINGER GR, CHANDEL NS: The Qo site of the mitochondrial complex III is required for the transduction of hypoxic signaling via reactive oxygen species production. J Cell Biol 177: 1029-1036, 2007.

BINDA E, ERHART D, SCHENK M, ZUFFEREY C, RENZULLI P, MUELLER C: Quantitative isolation of mouse and human intestinal intraepithelial lymphocytes by elutriation centrifugation. J Immunol Methods 344: 26-34, 2009.

BISCHOFF SC, SELLGE G, LORENTZ A, SEBALD W, RAAB R, MANNS MP: IL-4 enhances proliferation and mediator release in mature human mast cells. Proc Natl Acad Sci USA 96: 8080-8085, 1999.

BØYUM A, BRINCKER FJERDINGSTAD H, MARTINSEN I, LEA T, LØVHAUG D: Separation of human lymphocytes from citrated blood by density gradient (NycoPrep) centrifugation: monocyte depletion depending upon activation of membrane potassium channels. Scand J Immunol 56: 76-84, 2002.

BROWN ST, NURSE CA: Induction of HIF-2alpha is dependent on mitochondrial $\mathrm{O}_{2}$ consumption in an $\mathrm{O}_{2}$-sensitive adrenomedullary chromaffin cell line. Am J Physiol 294: C1305-C1312, 2008.

CHIANG SR, SU WJ, LEE PY, PERNG RP: Anaphylactic shock after readministration of rifampicin: a case report. Zhonghua Yi Xue Za Zhi 50: 509-512, 1992.

CHOTT A, GUENTHER P, HUEBNER A, SELZER E, PARWARESCH RM, HORNY HP, VALENT P: Morphologic and immunophenotypic properties of neoplastic cells in a case of mast cell sarcoma. Am J Surg Pathol 27: 1013-1019, 2003.

CHURUKIAN CJ, SCHENK EA: A toluidine blue method for demonstrating mast cells. J Histotechnol 4: 85-86, 1981.

CRUSE G, KAUR D, YANG W, DUFFY SM, BRIGHTLING CE, BRADDING P: Activation of human lung mast cells by monomeric immunoglobulin E. Eur Respir J 25: 858-863, 2005.

DE PAULIS A, ANNUNZIATO F, Di GIOIA L, ROMAGNANI S, CARFORA M, BELTRAME C, MARONE G, ROMAGNANI P: Expression of the chemokine receptor CCR3 on human mast cells. Int Arch Allergy Immunol 124: 146-150, 2001.

ETO DS, JONES TA, SUNDSBAK JL, MULVEY MA: Integrin-mediated host cell invasion by type 1-piliated uropathogenic Escherichia coli. PLoS Pathog 3: e100, 2007.

GNARPE H, ALFREDSSON H, BÖRSTAD B: Penicillin combinations against multi-resistant urinary pathogens as an alternative to gentamycin treatment. Microbios 16: 201-206, 1976. 
GURISH MF, FRIEND DS, WEBSTER M, GHILDYAL N, NICODEMUS CF, STEVENS RL: Mouse mast cells that possess segmented/multi-lobular nuclei. Blood 90: 382-390. 1997.

HERGET J, JEŽEK V: Pulmonary hypertension in chronic lung diseases. In: Hypertension: Problems and Controversies. H DODELIN, CA WAGENVOORT (eds), Elsevier, Amsterdam, 1989, pp 142-162.

HOLM M, ANDERSEN HB, HETLAND TE, DAHL C, HOFFMANN HJ, JUNKER S, SCHIOTZ PO: Seven week culture of functional human mast cells from buffy coat preparations. J Immunol Methods 336: 213-221, 2008.

HOLT PG, DEGEBRODT A, VENAILLE T, O'LEARY C, KRSKA K, FLEXMAN J, FARREL H, SHELLAM G, YOUNG P, PENHALE J, ROBERTSON T, PAPADIMITRIOU JM: Preparation of interstitial lung cells by enzymatic digestion of tissue slices: preliminary characterization by morphology and performance in functional assays. Immunology 54: 139-147, 1985.

HOSOI T, IMAI Y, IRIMURA T: Coordinated binding of sugar, calcium, and antibody to macrophage C-type lectin. Glycobiology 8: 791-798, 1998.

ITOH H, TAKAHASHI HK, IWAGAKI H, YOSHINO T, MORIMOTO Y, SAITO S, YAGI T, AKAGI T, NISHIBORI M, TANAKA N: Effect of histamine on intercellular adhesion molecule-1 expression and production of interferon-gamma and interleukin-12 in mixed lymphocyte reaction stimulated with interleukin18. Transplantation 74: 864-870, 2002.

KIM JY, LEE KH, LEE BK, RO JY: Peroxynitrite modulates release of inflammatory mediators from guinea pig lung mast cells activated by antigen-antibody reaction. Int Arch Allergy Immunol 137: 104-114, 2005.

KOHKA H, IWAGAKI H, YOSHINO T, KOBASHI K, URUSHIHARA N, YAGI T, TANIMOTO T, KURIMOTO M, AKAGI T, TANAKA N: Involvement of interleukin-18 (IL-18) in mixed lymphocyte reactions (MLR). J Interferon Cytokine Res 19: 1053-1057, 1999.

KOMENDA S: Tests for pair observations. In: Biometrics. I LEPKA (ed). University of Palacky, Olomouc, 1997, pp 96-101.

LAULAGNIER K, VINCENT-SCHNEIDER H, HAMDI S, SUBRA C, LANKAR D, RECORD M: Characterization of exosome subpopulations from RBL-2H3 cells using fluorescent lipids. Blood Cells Mol Dis 35: 116-121, 2005.

MANALO DJ, ROWAN A, LAVOIE T, NATARAJAN L, KELLY BD, YE SQ, GARCIA JG, SEMENZA GL: Transcriptional regulation of vascular endothelial cell responses to hypoxia by HIF-1. Blood 105: 659-669, 2005.

MAXOVÁ H, NOVOTNÁ J, VAJNER L, TOMÁŠOVÁ H, VYTÁŠEK R, VÍZEK M, BAČÁKOVÁ L, VALOUŠKOVÁ V, ELIAŠOVÁ T, HERGET J: In vitro hypoxia increases production of matrix metalloproteinases and tryptase in isolated rat lung mast cells. Physiol Res 57: 903-910, 2008.

MIYASAKI KT, BODEAU AL: Human neutrophil azurocidin synergizes with leukocyte elastase and cathepsin G in the killing of Capnocytophaga sputigena. Infect Immun 60: 4973-4975, 1992.

NABE T, YAMAMURA H, HATANAKA M, SHINODA N, SHIMIZU K, MIZUTANI N, YAMASHITA K, HORIBA M, KOHNO S: Ability of teicoplanin and vancomycin to induce contraction of, and histamine release from, pulmonary tissue of humans, monkeys and guinea pigs. J Antimicrob Chemother 43: 233-242, 1999.

NESSI R, BONOLDI GL, REDAELLI B, DI FILIPPO G: Acute renal failure after rifampicin: a case report and survey of the literature. Nephron 16: 148-159, 1976.

NEWMAN SL, GOOTEE L, GABAY JE, SELSTED ME: Identification of constituents of human neutrophil azurophil granules that mediate fungistasis against Histoplasma capsulatum. Infect Immun 68: 5668-5672, 2000.

NOVOTNÁ J, HERGET J: Possible role of matrix metalloproteinases in reconstruction of peripheral pulmonary arteries induced by hypoxia. Physiol Res 51: 323-334, 2002.

ONOSE J, XIE C, YE YQ, SUGAYA K, TAKAHASHI S, KOSHINO H, YASUNAGA K, ABE N, YOSHIKAWA K: Vialinin A, a novel potent inhibitor of TNF-alpha production from RBL-2H3 cells. Biol Pharm Bull 31: 831$833,2008$.

SKOKOS D, GOUBRAN-BOTROS H, ROA M, MÉCHERI S: Immunoregulatory properties of mast cell-derived exosomes. Mol Immunol 38: 1359-1362, 2002.

SMITH JW: Allostery and proteolysis: two novel modes of regulating integrin function. Matrix Biol 16: 173-178, 1997. 
SUZUKI M, FURUNO T, TESHIMA R, SAWADA J, NAKANISHI M: Soluble factors from rat basophilic leukemia (RBL-2H3) cells stimulated cooperatively the neurite outgrowth of PC12 cells. Biol Pharm Bull 21: 1267$1270,1998$.

THEOHARIDES TC, KEMPURAJ D, TAGEN M, CONTI P, KALOGEROMITROS D: Differential release of mast cell mediators and the pathogenesis of inflammation. Immunol Rev 217: 65-78, 2007.

TOYOGUCHI T, EBIHARA M, OJIMA F, HOSOYA J, SHOJI T, NAKAGAWA Y: Histamine release induced by antimicrobial agents and effects of antimicrobial agents on vancomycin-induced histamine release from rat peritoneal mast cells. J Pharm Pharmacol 52: 327-331, 2000.

VAJNER L, VYTÁŠEK R, LACHMANOVÁ V, UHLÍK J, KONRÁDOVÁ V, NOVOTNÁ J, HAMPL V, HERGET J: Acute and chronic hypoxia as well as 7-day recovery from chronic hypoxia affects the distribution of pulmonary mast cells and their MMP-13 expression in rats. Int J Exp Pathol 87: 383-391, 2006.

WEINGARTEN H, FEDER J: Cleavage site specificity of vertebrate collagenase. Biochem Biophys Res Commun 139: 1184-1187, 1986.

WILLHEIM M, AGIS H, SPERR WR, KOLLER M, BANKL H-C, KIENER H, FRITSCH G, FUREDER W, SPITTLER A, GRANINGER W, SCHEINER O, GADNER H, LECHNER K, BOLTZ-NITULESCU G, VALENT P: Purification of human basophils and mast cells by multistep separation technique and $\mathrm{mAb}$ to CDw17 and CD117/c-kit. J Immunol Methods 182: 115-129, 1995.

WU Y, HU J, ZHANG R, ZHOU C, XU Y, GUAN X, LI S: Enhanced intracellular calcium induced by urocortin is involved in degranulation of rat lung mast cells. Cell Physiol Biochem 21: 173-182, 2008.

YU Y, YU Y, HUANG H, FENG K, PAN M, YUAN S, HUANG S, WU T, GUO L, DONG M, CHEN S, XU A: A short-form C-type lectin from Amphioxus acts as a direct microbial killing protein via interaction with peptidoglycan and glucan. J Immunol 179: 8425-8434, 2007.

ZELENSKY AN, GREADY JE: The C-type lectin-like domain superfamily. FEBS J 272: 6179-6217, 2005.

ZVÁROVÁ J: Comparison of two groups. In: Biomedical Statistics I. Fundaments of Statistics for Biomedicine Branches. V BENCKO, J MACHEK, K HRACH (eds), Karolinum, Prague, 2001, pp 121-139. 